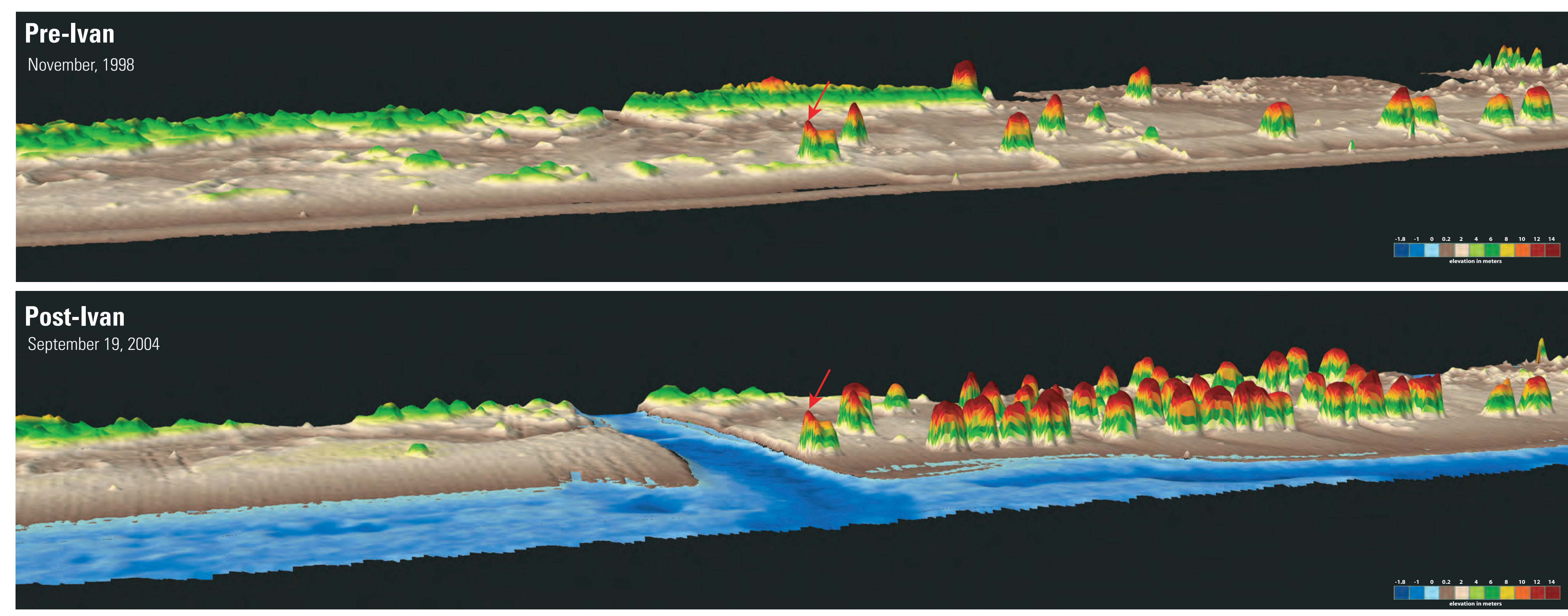

\title{
Post-lvan
}

September 17, 2004

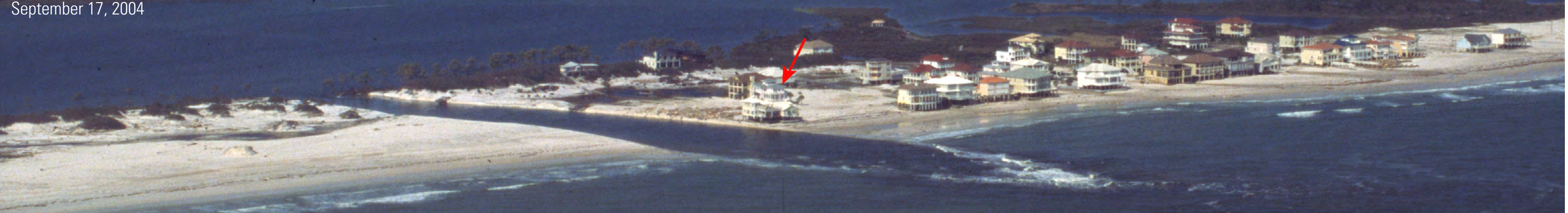



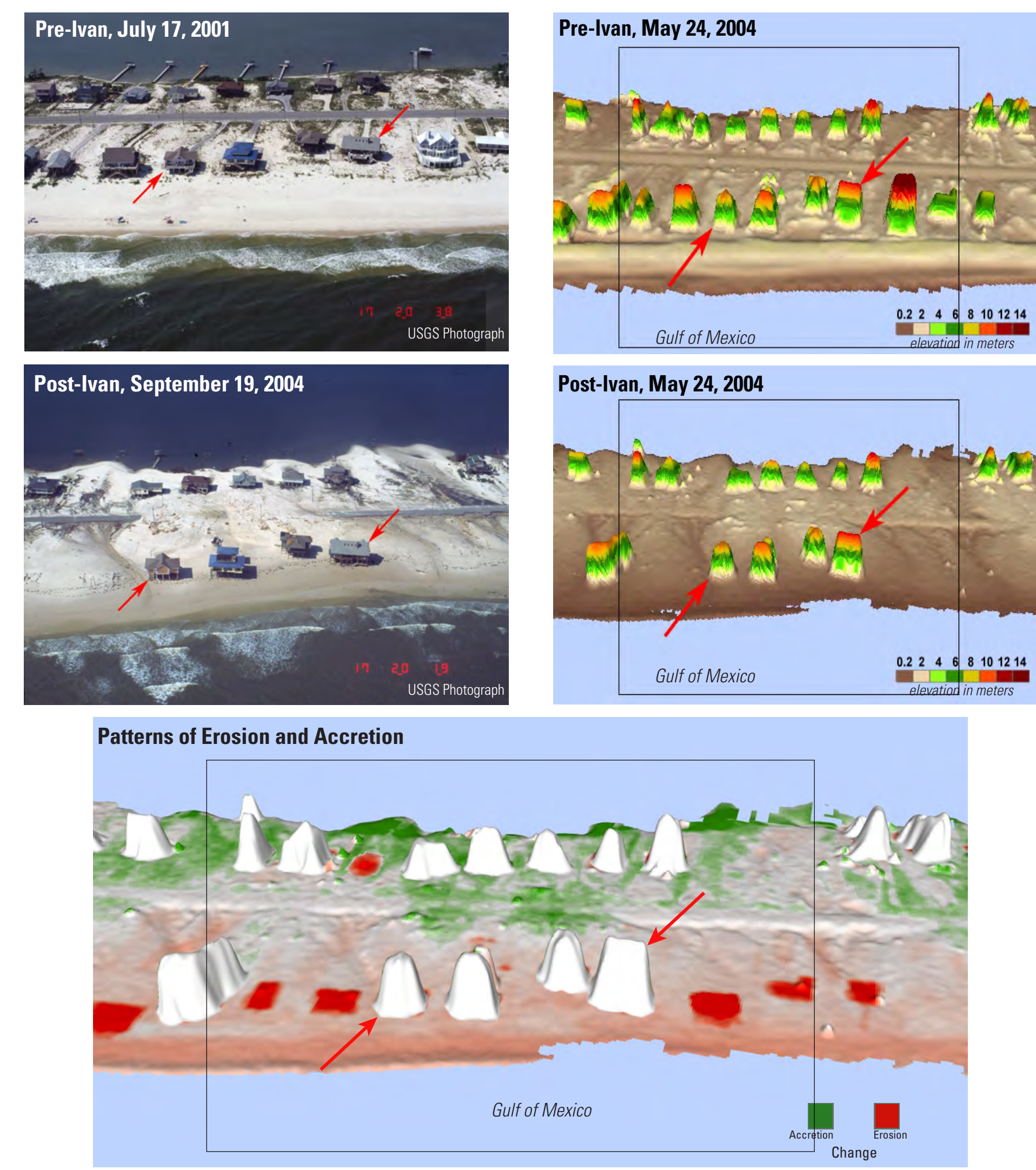

Figure 4. Gulf Shores, Alabama. Upper left: USGS before and after aerial photographs showing the loss of houses during Ivan. Upper right: Before and after laser mapping (lidar) topography of the same area shown in the photos (warmer colors represent higher elevations, (for example, houses). Bottom center. Vertical elevation change (erosion and accretion) that occurred as a result of the storm. The red rectangles indicate houses that were completely destroyed and swept from the island into the back bay. (Arrows in all images
point to the same features. Black lines in lidar images indic ate limits of photos. )

Author: Karen L. M. Morgan, USGS kmorgan@usgs.gov 727-803-8747 x 3037

Project Contact: Asbury (Abby) Sallenger, USGS asallenger@usgs.gov 727-803-8747 x 3015 http://coastal.er.usgs.gov/hurricanes/

\section{Coastal Change During Hurricane Ivan 2004}

Category 3 Hurricane Ivan came ashore near Gulf Shores, Alabama on September 16, 2004. The barrier islands of the northern Gulf of Mexico near the Florida/Alabama border were exposed to the strongest winds. The communities of Gulf Shores, Pine Beach, and Orange Beach, Alabama, are, in places, very low lying with their dunes rising up only several meters. These dunes were unable to contain the 3- to 4-m storm surge (USGS) National Aeronautics (USGS), National Aeronautics Space Administration (NASA) and U.S. Army Corps of Engiin a research project investigating in a research project investigating Ivan. On Friday, September 17, 2004, the USGS acquired oblique aerial photography to better understand the impact of Ivan on the coastal environment. On Sunday, September 19, 2004, airborne lidar was collected using NASA Experimental Advanced Airborne Research Lidar (EAARL).

Gulf waters driven by hurricaneforce winds spilled across the barrier islands as storm surge and created currents strong enough to transport massive amounts of sand landward. These waters undermined buildings and roads and opened new island breaches. On top of the surge, breaking waves surge, eroded dunes and battered Figure 2 Figure 1. Map showing track of Huricane Ivan.

U.S. Department of the Interior
U.S. Geological Survey

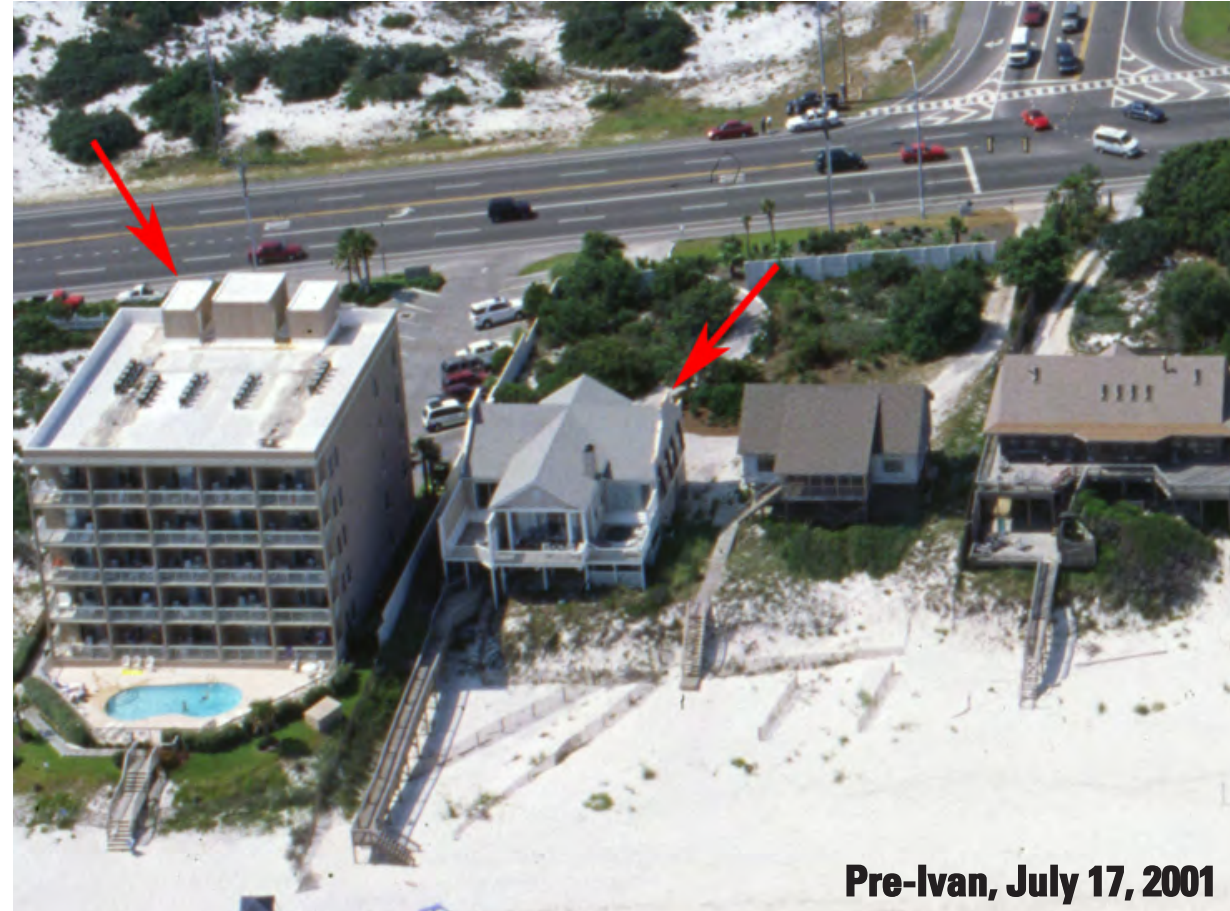

I
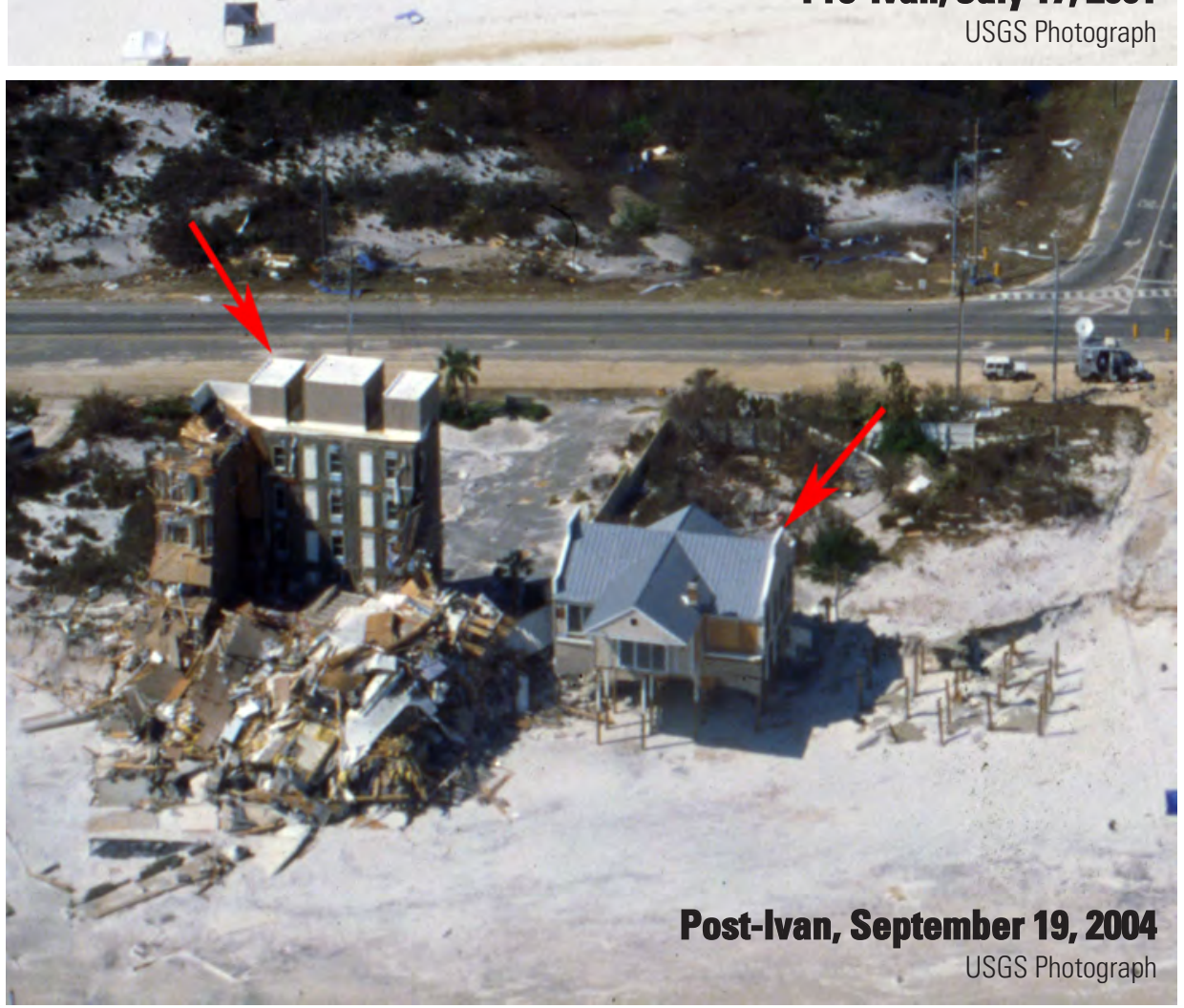

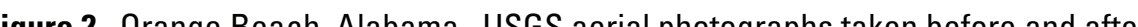
e landfall of Hurricane Ivan show the failure of a five-story condominium tower. The only parts of the structure that remain standing after Hurricane Ivan are the elevator is storm. (Arrows in all images point to the same feature.)

(2) Printed on recycled paper

Fact Sheet 2009-3026
March 2009 